\title{
RESPONSIVENESS OF MOTOR INSURANCE BUSINESS TO INSURANCE SECTOR DEVELOPMENT, 2005-2016. ECONOMETRIC EVIDENCE FROM NIGERIA
}

\section{EZEMA, Clifford Anene}

Department of Insurance and Risk Management, Faculty of Management Sciences, Enugu State University Of Science and Technology,(ESUT),ENUGU, Ezemaclifford10@ gmail.com

ANI, Afamefuna Jonah

Department of Insurance, School of Financial Studies

Institute of Management and Technology, Enugu

afaminsurance@gmail.com

\begin{abstract}
The study assessed the responsiveness of Motor Insurance Business to Insurance Sector Development in Nigeria, 2005-2016. The study used Ex-post facto research design. Ordinary least square model was used as analytical technique. Result reveals that insurance penetration positively and significantly responds to total premium generated in motor insurance and also total claims paid in motor insurance. Also, insurance density positively and significantly responds to total premium generated in motor insurance and also negatively to total claims paid in motor insurance business in Nigeria; Based on the findings of the study it was concluded that motor insurance premium and claims positively and non-significantly responds to insurance penetration and insurance density but insurance density has a negative response on insurance claims settlements in Nigeria. It was recommended that the insurance industry should design policies that will bring in new deals like covering tri-cycle riders in the country. This can widen the number of vehicles insured and deepen insurance penetration.

Keywords: Insurance penetration, Insurance density, Motor Insurance Business
\end{abstract}

\section{Introduction}

Development is imperials and essential to the growth of any nation. A country is classified as developed when she is able to provide qualitative life for her citizenry (Oye, 2014).Development is an ever-changing step towards achieving some goal and the optimum realization of the well being of people in their communities (Ejumudo, 2013). It is not an absolute but a relative term because it is difficult to measure, especially as a particular activity may be considered development or a step forward in a particular society, but it may not be so considered in another society. Development is very much related with aspirations and expectations of the people. It is interaction of the people with the natural resources available to them. Quite often, development is viewed as some dynamic change of society from one stage to another without assuming that it is the final stage. Oye (2014) defined development as the transformation of community into socially, economically, politically, educationally, orderly, and materially desirable conditions, with the aim of improving the quality of life of the people. It is also referred to as the uniform distribution of resources, the integration of the people into national economy; it is a socio-economic process which seeks to bring about a more equitable distribution of resources and income within the society.

One of the means of facilitating development is through transportation. This deals primarily with the mobility of people, goods and services. Transportation is a process thatinvolves the movement of commuters, goods and services from a given point of origin to a specific 
destination (Okoko, 2006). It is the engine that drives the growth and development of people and countries (Efobi and Anierobi, 2014). It is a means to access business activities, education, employment and recreational opportunities, thus contributing to policy effectiveness and enhancement of security through reduced isolation as well as providing job opportunities (World Bank, 2002). Transportation is the basis for economic, social and political development in most societies as it exhibits a close relationship to the style and quality of living of the society. Transportation plays an important role in the day-to -day activities of the society. In most communities, a large fraction of the working population travels daily in one form ofmechanized vehicles or the other to and from work not to mention journeys made for recreation,shopping and other social activities goods are also shipped over a long distance to provide thosematerials, which are part of the expected standard of living. However transportation is fraught with lots of risk. In order to combat the loss being suffered from transportation risks the society turns to insurance. Ogwo, Eche, Ibeabuchi, Nwite and Enwereuzo (2000) assert that any device aimed at reducing the chance of a risk occurring or when it happen reduces the extent of its damage and providing the affected person with compensation is a form of insurance. The indemnification and risk pooling properties of insurance facilitate commercial transactions and the provision of credit by mitigating losses as well as the measurement and management of non diversifiable risk more generally (Brainard, 2008).

Motor insurance is the class of insurance that mitigates transportation risks. By the end of the First World War (1918) people were returning from the conflict with an interest to continue their driving experience. By 1920s' there were so many motor vehicles in England that legislation was almost invisible and in 1930 the Road Traffic Act 1930 was passed (Enoka, 2012). The intention of the act, inter alias, was to ensure that funds would be available to compensate the innocent victims of motor accidents. This was to be provided by means of insurance against legal liability to pay damages to injured persons. The insurance requirement applied to all users of motor vehicles, except where some special legal arrangement is in force. Motor insurance, also called automotive insurance, is a contract by which the insurer assumes the risk of any loss the owner or operator of a car may incur through damage to property or persons as the result of an accident.

There are many specific forms of motor vehicle insurance, varying not only in the kinds of risk that they cover but also in the legal principles underlying them. Types of motor insurance include Third Party Insurance; Comprehensive Insurance; Fire and Theft Only; and Third Party Property Only. Okoko (2006) stated that If you own a car and want to drive on Nigerian roads, Third Party Car Insurance is the minimum level of cover required by law. However, the cover provided by this type of policy is very basic. Third party cover simply agrees to pay for damage caused to other people's property, or compensation or costs related to injuries they sustain, in an incident adjudged to be the fault of the covered driver. So this cover would pay out if you caused an accident and injured another driver - or their passenger.

Despite its uniqueness, insurance, like any other business, requires adequate capital to function effectively as adequate capital is required to maintain public confidence by standing ready to absorb unexpected or unusual losses not absorbed by normal earnings (Nwankwo, 1991). The capacity of an insurer or the industry as a whole to indemnify determines its level of development (Nwoji, 2017). Despite efforts by insurance sector operators and regulators to deepen insurance penetration in Nigeria and boost the sector's contributions to the Gross Domestic Product (GDP), the sector merely recorded 0.32 percent growth in third quarter 2017. This depicts an abysmal performance that is -24.53 percent lower than its growth performance in the corresponding period in 2016 and -21.56 percent lower than the growth rate achieved by the sector in the preceding quarter. According to the third quarter 2017 GDP report released recently by the National Bureau of Statistics (NBS), the Finance and Insurance 
Sector consist of the two sub sectors, Financial Institutions and Insurance, which account for 87.09percent and 12.91 percent of the sector respectively in real terms. As a whole, the sector grew at -3.88 percent in nominal terms (year on year), with the growth rate of Financial Institutions as -4.47 percent and 0.32 percent growth rate by the Insurance sector (Nwoji, 2017). The overall growth rate was lower than that in third quarter of 2016 by -24.53 percent points, and lower by -21.56 percent points than the preceding quarter. The sector's contribution to the overall nominal GDP was 3.04 percent in third quarter of 2017, lower than the 3.51 percent it represented a year previous, and yet lower from the contribution of 3.75 percent it made in the preceding quarter. This by interpretation means that the insurance industry is far below expectation.It can be seen from the above that assessing insurance development usually measures the industry as a whole. Cognizance is not given to the classes that exist in insurance. Thereby we are denied an understanding of specific impact of the respective classes of insurance on insurance development. Motor insurance is one of the classes of insurance through which the industry combats transportation risk. It is the class of insurance with the highest demand in Nigeria (Efina, 2011). In this position the motor class may pull significant influence on development of the industry. Therefore, this study seeks to assess the responsiveness of motor insurance business to insurance sector development in Nigeria. Empirical study of classes of insurance as factors behind insurance development has received minimal academic consideration. Insurance penetration shows the level of development of insurance sector in a country. Penetration rate is measured as the ratio of premium underwritten in a particular year to the GDP. Insurance Penetration - refers to a product's sales volume relative to the sales volume of competing products. Insurance density is used as an indicator for the development of insurance within a country and is calculated as the ratio of total insurance premiums to whole population of a given country. Therefore, this study seeks to examine the responsiveness of motor insurance business to insurance sector development in Nigeria.The broad objective of the study is to assess the responsiveness of the motor insurance business to development of insurance in Nigeria while the specific objectives of the study are to:Examine the contribution of motor insurance premium to insurance penetration in Nigeria.Determine the contribution of motor insurance premium to insurance density in Nigeria. Investigate the contribution of motor insurance claims to insurance penetration in Nigeria.Ascertain thecontribution of motor insurance claims to insurance density in Nigeria. The remainder of this paper is arranged as follows: next section reviews of related literature. Next section presents data methodology and specifies model used in the study, then, next section presents results while the last section concludes the paper.

\section{REVIEW OF RELATED LITERATURE Empirical review}

Greene and Segal (2000) explored the relationship between operational efficiency and profitability and growth in the US life Insurance industry, and provided a framework for linking operating performance and financial success. Regression was used as analysis technique. The results suggest that operational inefficiency in the life insurance industry is substantial relative to earnings, and that inefficiency is negatively associated with profitability measures such as the return on equity (ROE) and growth. Similarly, it's found that relatively efficient firms have higher ROE, growth, and other profitability measures. Also, it's found that stock (shareholder-owned) companies are more efficient and profitable and grow faster than mutual (policyholder-owned) companies.

Awunyo(2012) examined the determinants of comprehensive motor insurance demand in Ghana. The study used logit model to assess factors influencing demand for comprehensive motor insurance. The results revealed that, demand for comprehensive motor insurance is 
significantly influenced by income, value of the vehicle, age of the vehicle, perception of the premium and claim procedure.

Ibrahim (2013) examined factors influencing performance of the insurance industry in Tanzania. Simple Regression was used in the study. The study revealed that performance of ZIC were affected by insured by delaying to pay premium on time, to report fake claim and lack of know how about insurance service. The result also found that operations of insurance company were influenced by Assessors and Investigator due to delaying in producing report on time.

Ajemunigbohun and Oreshile (2014) analyzed risk attitude and demand for motor insurance: An examination of selected motorists in Lagos State, Nigeria. The statistical instruments employed for this study was Multiple regression. Results of. the research evidenced a significant interrelationship between the understudied constructs .i.e. drivers' risk attitude, risk occurrence and motor insurance demand.

Libuli, Sakataka, and Wandera (2014) ran an Assessment of Operational Strategies Influencing the Growth of Insurance Industry in Uasin Gishu County, Kenya. Data was analyzed by descriptive statistics techniques such as percentages. The study has made appropriate recommendations to all stake holders on what needs to be done to improve the growth of Insurance in the County by stressing on awareness creation.

Murrira and Bosire (2016) undertook a study on assessment of factors influencing revenue growth of insurance companies in Nakuru town, Kenya. Through correlation analysis, premiums rate cutting, investments earning trends and financial leverage showed strong, positive association while interest rates illustrated little effect implying insufficient evidence to stamp its importance concerning the revenue growth. Regression analysis indicated that all study independent variables jointly had strong relationship with revenue growth portraying greater influence on same matter.

Njuguna and Kimani (2016) assessed the effect of financial factors on insurance penetration in Nakuru town, Kenya. Descriptive statistics included means, modes and standard deviations. Inferential statistics included Pearson's Product Moment Correlation and multiple regression analysis. The study found that all the financial factors investigated had significant relationship with insurance penetration. The study concluded that insurance firms incur administrative and agency costs that hamper insurance penetration. The study recommended that insurance firms need to arrest escalating costs associated with administrative functions and agency.

Ward and Zurbruegg (2000) examined the potential causal relationship between economic growth and insurance market activity for nine OECD countries for the period 1961-1996, using annual real GDP as a measure of economic activity and annual real total written premiums as a measure of insurance activity using VAR. Result reveals a long-run relationship for five countries (Australia, Canada, France, Italy, and Japan). In order to assess causation between insurance and GDP growth for four countries (Australia, Canada, Italy, and Japan), Result reveals causation for three countries (Australia, Canada, and Japan).

Webb, et. al (2002) examined the causal relationship of banks, life, and non-life insurance activity on economic growth in some selected European countries using two ways leastsquares method. Results reveal that the exogenous components of the banking and life insurance measures are found to be robustly predictive of increased economic growth.

Kugler and Ofoghi (2005) evaluated both a long-run relationship and Granger-causality between insurance size and economic growth for the United Kingdom using net premium for each insurance (general and long-term insurance) in the UK for the period 1966-2003. Using Johansen's co-integration test, Result reveals a long-run relationship between 
development in insurance market size and economic growth for all insurance components. Regarding causality tests, there is evidence of long-run causality from growth in insurance market size to GDP growth for eight out of nine insurance categories that are considered. Short-run causality exits from life, liability and pecuniary loss insurance. As the authors point out in the paper, these results do not permit to make a definitive conclusion regarding causality.

Adams (2005) examined empirically the dynamic historical relation between banking, insurance and economic growth in Sweden from 1830 to 1998 using co-integration and Granger causality tests. Their results indicate that the development of banking, but not insurance preceded economic growth in Sweden during the nineteenth century, while Grangercausality was reverse in the twentieth century. The insurance market appears to be driven more by the pace of growth in the economy rather than leading economic development.

Outreville (1990) examined the relationship between property-liability insurance premium and economic and financial development with a cross-section of 55 developing countries. A positive relationship between logarithm of property-liability premium per capita and GDP per capital was found. It was argued that $1 \%$ increases in GDP causes more than $1 \%$ increase in demand. A positive relationship between insurance development (defined as insurance penetration or ratio of insurance premium to GDP) and financial development (ratio of M2 to GDP) was reported by using OLS method. He reported that the income elasticity was greater than one and a positive relationship between demand for insurance and financial development, but the coefficient for price was not statistically significant.

Haiss and Sumeji (2008) investigated both the impact of insurance investment and premiums on GDP growth in Europe and conducted a cross-country panel data analysis from 1992 to 2005 for 29 European countries. They found a positive impact of life insurance on GDP growth in 15 EU countries, among which were Switzerland, Norway and Iceland. For the New EU Member States from Central and Eastern Europe, they found a larger impact for liability insurance. Furthermore their findings emphasized the impact of the real interest rate and the level of economic development on the insurance-growth nexus. They argued that the insurance sector needed to be paid more attention to in financial sector analysis and macroeconomics policy.

Mojekwu (2011) examined the impact of insurance contributions on economic growth in Nigeria, 1981 and 2008 using dynamic factor model of correlation which described a number of methods designed to analyses a functional relationship between the volume of insurance contribution and economic growth in terms of underlying but unobservable random quantities called factors. The factor loadings indicated which common trend is related to which set of the series. The study found a functional positive relationship between the volume of insurance contributions and economic growth in Nigeria.

Pen-Fen et al. (2011) investigated the effect of life insurance on economic growth and what conditions affect the insurance-growth nexus. These conditions include the degree of financial development, private saving rates, interest rates, social security expenditures, income, young dependency ratio, life expectancy, and geographic regions. The main findings confirmed the positive impact of the development of the life insurance on economic growth. The insurance-growth nexus varied across countries with different conditions. For example, the positive impact on economic growth is less in the middle- income countries, but high in 
the low-income countries. Moreover, they found that the development of stock market and the life insurance market are substitutes rather than complements.

Marijuana (2009) empirically examined the relationship between insurance sector development and economic growth in 10 transition European Union. Three different insurance variables were used; life, non-life and total insurance and other control variables like education, openness, inflation, investment, bank credit, stock capitalization. According to their findings, insurance sector development positively and significantly affects economic growth. The results are confirmed in terms of life and non-life insurance, as well as total insurance.

\section{Knowledge gap}

Looking at the empirical reviews above, some of the review differs by location; all seem to center on the impact of insurance on economic development of various countries. None of the literatures worked on responsiveness of motor Insurance to insurance sector development in Nigeria; hence, the study wants to fill the gap so as to contribute to knowledge

\section{METHODOLOGY}

\section{Research design}

Ex-post facto research method was used as research design. It was considered appropriate given that time series data (already organized data) was used in the study.Secondary data was used in the study. Secondary data refers to data that has already been collected by and readily available from other sources (Egbulonu, 2007). The data were taken from Central Bank of Nigeria Statistical Bulletin, 2016.

\section{Model specification}

The functional relation of the model is given as:

$$
\begin{aligned}
& \text { INSPEN }=\beta_{0}+\beta_{1} \text { MOTPRE }+\mu \ldots \text { (i) } \\
& \text { INSDEN }=\beta_{0}+\beta_{1} \text { MOTPRE }+\mu \ldots \text { (ii) } \\
& \text { INSPEN }=\beta_{0}+\beta_{1} \text { MOTCLA }+\mu \ldots \text { (iii) } \\
& \text { INSDEN }=\beta_{0}+\beta_{1} \text { MOTCLA }+\mu \ldots \text { (iv) } \\
& \text { Where: }
\end{aligned}
$$

MOTPRE $=$ Motor insurance gross written premium;MOTCLA $=$ Motor insurance claims settlement; INSPEN = Insurance penetration;INSDEN = Insurance Density;

$\beta_{0},=$ Intercept; $\beta_{1}=$ Coefficient parameter; $\mu=$ error term

\section{Explanation of model variables Independent variables}

Ratio of Motor insurance gross written premium to GDP: This refers to the total monetary value of all motor vehicle policies sold in a particular business year. This is measured by Motor insurance gross written premium divided by GDP

Ratio of Motor insurance claims settlement to GDP: This refers to the total amount spent insurance companies in settling loss incurred by insured with motor vehicle cover. This is measured by Motor insurance claims settlement divided by GDP

\section{Dependent variable}

Insurance Penetration: This is the ratio of total insurance premiums to gross domestic product of a given country

Insurance Density: This is the ratio of total insurance premiums to whole population of a given country. 


\section{Presentation of Data}

Table 4.1.1 Data in on Insurance penetration, Insurance density, Motor premium and Motor claims settlement

\begin{tabular}{|l|l|l|l|l|}
\hline YEAR & RMOPREGDP & RMOCLAGDP & INSPEN & INSDEN \\
\hline 2005 & 0.732943 & 0.167642 & 0.556911 & 0.301022 \\
\hline 2006 & 0.723419 & 0.723419 & 2.661184 & 0.271841 \\
\hline 2007 & 0.781069 & 0.187787 & 0.761727 & 0.246531 \\
\hline 2008 & 0.988337 & 0.253729 & 0.955428 & 0.265566 \\
\hline 2009 & 1.084345 & 0.398765 & 1.487655 & 0.212347 \\
\hline 2010 & 0.804318 & 0.242052 & 0.985408 & 0.245637 \\
\hline 2011 & 0.721205 & 0.209678 & 0.955929 & 0.219345 \\
\hline 2012 & 0.767053 & 0.224236 & 0.839513 & 0.267102 \\
\hline 2013 & 0.827122 & 0.323829 & 0.751696 & 0.43079 \\
\hline 2014 & 0.489994 & 0.163045 & 0.676127 & 0.241145 \\
\hline 2015 & 0.427928 & 0.183276 & 0.639498 & 0.286598 \\
\hline 2016 & 0.408200 & 0.801773 & 0.593212 & 0.135158 \\
\hline
\end{tabular}

Source: Author's compilation using data from Appendix One

Where:

RMOPREGDP $=$ Ratio of motor insurance premium to Gross Domestic Product. RMOCLAGDP = Ratio of motor claims to Gross Domestic Product

INSPEN = Ratio of total insurance industry premium to Gross Domestic Product. INSDEN = Ratio of total insurance premium to population of the country

In 2005 the Ratio of motor insurance premium to Gross Domestic Product was 0.732943 . By 2010 it rose to 0.804318 . In 2016 it was 408200.3.For Ratio of motor claims to Gross Domestic Product was 0.167642 in 2005 . It was 0.242052 by 2010 and 80177.3 in 80177.3. Insurance penetration in 2005 was 0.556911 . By 2010 it was 0.245637 . In 2016 it arrived at 0.593212 . Insurance density by 2005 was 0.301022 . By 2010 it arrived at 0.245637 and was 135158 in 2016.

Table 4.1.2 Descriptive Statistics

$\begin{array}{lccll}\text { Mean } & \text { INSDEN } & \text { INSPEN } & \text { RCLAGDP } & \text { RPREGDP } \\ \text { Median } & 35146.58 & 0.981327 & 21954.74 & 69678.04 \\ \text { Maximum } & 0.266334 & 0.800616 & 0.247891 & 0.792689 \\ \text { Minimum } & 286598.3 & 2.661184 & 183276.7 & 427928.4 \\ \text { Std. Dev. } & 0.210432 & 0.556911 & 0.163045 & 0.489994 \\ \text { Skewness } & 88205.79 & 0.576809 & 55787.45 & 162785.4 \\ \text { Kurtosis } & 2.278092 & 2.268324 & 2.346070 & 1.791540 \\ \text { Jarque-Bera } & 6.738677 & 7.236092 & 7.076088 & 4.214411 \\ \text { Probability } & 17.36826 & 19.26283 & 19.31534 & 7.156630 \\ & 0.000169 & 0.000066 & 0.000064 & 0.027923 \\ \text { Sum } & 421759.0 & 11.77592 & 263456.8 & 836136.5 \\ \text { Sum Sq. Dev. } & 8.56 \mathrm{E}+10 & 3.659795 & 3.42 \mathrm{E}+10 & 2.91 \mathrm{E}+11 \\ & & & & \\ \text { Observations } & 12 & 12 & 12 & 12 \\ \text { Source: Author's calculation using Eviews } & & \end{array}$


Insurance density, Motor claims and Motor premium recorded high standard deviations. It shows that their data tends to move away from the mean. Therefore the data shows high tendency to volatility. On the other hand, Insurance penetration had higher jarque bera statistics and are normally distributed. All the variables are leptokurtic showing they are highly peaked.

Table 4.1.3 Results of Unit Root Test

\begin{tabular}{|l|l|l|l|l|}
\hline & RMOPREGDP & RMOCLAGDP & INSPEN & INSDEN \\
\hline $\begin{array}{l}\text { Phillips- } \\
\text { Perron test } \\
\text { statistic }\end{array}$ & -5.789609 & & & \\
\hline $\begin{array}{l}\text { Test critical } \\
\text { values }\end{array}$ & -4.420595 & -7.166775 & -18.34398 & -7.075767 \\
\cline { 2 - 5 } & -3.259808 & -3.259808 & -4.420595 & -4.420595 \\
\cline { 2 - 5 } & -2.771129 & -2.771129 & -3.259808 & -3.259808 \\
\hline $\begin{array}{l}\text { Order of } \\
\text { Integration }\end{array}$ & $1(2)$ & $1(0)$ & $1(2)$ & -2.771129 \\
\hline
\end{tabular}

Source: Author's calculation using Eviews

Unit root test was run using Phillips Perron method. At level and first difference there was no stationary. This was achieved at second difference. Therefore, the variables are integrated of order two.

TABLE 4.1.4 REGRESSION RESULT (1)

Dependent Variable: INSPEN

Method: Least Squares

Date: 11/04/18 Time: 13:03

Sample: 20052016

Included observations: 12

\begin{tabular}{lllcl}
\hline \hline Variable & Coefficient & Std. Error & t-Statistic & Prob. \\
\hline \hline C & -0.508342 & 0.661102 & -0.768931 & 0.4616 \\
PRGDP & 1.340937 & 0.769501 & 1.742605 & 0.1154 \\
CLGDP & 1.652889 & 0.689790 & 2.396219 & 0.0401 \\
\hline \hline R-squared & 0.841344 & Mean dependent var & 0.981384 \\
Adjusted R-squared & 0.817198 & S.D. dependent var & 0.576855 \\
S.E. of regression & 0.476665 & Akaike info criterion & 1.568314 \\
Sum squared resid & 2.044889 & Schwarz criterion & 1.689540 \\
Log likelihood & -6.409883 & Hannan-Quinn criter. & 1.523431 \\
F-statistic & 3.555048 & Durbin-Watson stat & 2.181447 \\
Prob(F-statistic) & 0.032803 & & \\
\hline \hline
\end{tabular}




\section{TABLE 4.1.5 REGRESSION RESULT}

Dependent Variable: INSDEN

Method: Least Squares

Date: 11/04/18 Time: 13:06

Sample: 20052016

Included observations: 12

\begin{tabular}{lllll}
\hline \hline Variable & \multicolumn{2}{l}{ Coefficient Std. Error } & t-Statistic & Prob. \\
\hline \hline C & 0.240974 & 0.099148 & 2.430458 & 0.0380 \\
PRGDP & 0.764995 & 0.115405 & 0.563196 & 0.0071 \\
CLGDP & -0.091144 & 0.103450 & -0.881042 & 0.4012 \\
\hline \hline R-squared & 0.787980 & Mean dependent var & 0.259228 \\
Adjusted R-squared & 0.753580 & S.D. dependent var & 0.069646 \\
S.E. of regression & 0.071487 & Akaike info criterion & -2.226284 \\
Sum squared resid & 0.045994 & Schwarz criterion & -2.105057 \\
Log likelihood & 16.35770 & Hannan-Quinn criter. & -2.271167 \\
F-statistic & 7.720297 & Durbin-Watson stat & 1.940798 \\
Prob(F-statistic) & 0.000658 & & &
\end{tabular}

\section{Conclusion and Recommendation}

The insurance industry in Nigeria is made up of three main sectors, Life, Non-life and Reinsurance sectors. Each pulls a measure of influence in the industry. To an extent they respectively contribute towards developing the industry. The motor insurance class has been most favored in patronage by Nigerians. Motor insurance has accounted for the majority of premiums for the past five years. It has been equally identified that Motor insurance as the most widely used class of non-life insurance business. Therefore, the motor insurance business makes significant contribution to insurance industry. In line with this position, this study assessed the responsiveness of the motor insurance class to insurance sector development in Nigeria. This is becauseinsurance penetration positively but non significantly responded to insurance premium and also positively and significantly responded claims payment showing that insurance penetration positively drives insurance premium and insurance claims in Nigeria. Also insurance density positively but non significantly responded to insurance premium and also negatively and significantly responded claims payment showing that insurance density positively drives insurance premium and negatively responds to insurance claims in Nigeria. Based on the findings of the study, the following recommendations were made:

The insurance industry should design policies that will bring in new deals like covering tricycle riders in the country. This can widen the number of vehicles insured and deepen insurance penetration. Motor insurance service providers should from time to time conduct promos for persons living within a particular area to woo them into buying a new policy. This can increase premium revenue and in extension insurance density in that area. The specific claims paid for motor insurance coverage should be made an instrument of awareness that can draw non-customers to appreciate insurance and start buying policies. This can deepen insurance penetration. Special discounts should be given to motor insurance customers who have lived in a given area consistently for a long period as a way to deepen insurance density. 


\section{References}

1. Adams, B. (2008), The Insurance Industry and Nigerian Economy, Light does not Shine in Light. Journal of Economic survey 22(3).

2. Ajemunigbohun, S. S. \&Oreshile, A. S. (2014). Risk attitude and demand for motor insurance: An examination of selected motorists in LagosState, Nigeria.DevelopingCountryStudies. 4 (21), 144-154

3. Arena, M. (2006). Does insurance market promote economic growth and employment in the EU.Journal of Risk and Insurance, 34(5)921-

4. Awunyo-Vitor D. (2012).Comprehensive motor insurance demand in Ghana: Evidence from Kumasi metropolis. management, 2(4)

5. Boon TK (2005). Do Commercial Banks, Stock market and Insurance Market Promote Economic Growth? An analysis of the Singapore Economy, working paper of the school of Humanities and Social Studies, Nanyang Technological University.

6. Beenstock M, Dickinson G, Khajuria S (1988). "The determination of life premium: An International Cross-section Analysis 1970-1981”. Insur.Math.Econom., pp. 261-270

7. Brainard, J.I. (208). The Position of Insurance Industry in Nigeria in the Consolidation Era. Paper Presented during Insurance Student Dinner and Award night at universalhotel Enugu.

8. Brown MJ, Kim K (1993). "An international Analysis of life Insurance€ Demand".American Risk and Insurance Association. J. Risk Insur., 60(4): 616-634.

9. Efola, S.O.N, \& Anierobi, A.N (2014).Predicting insurance investment: a factor analytic approach. Journal of Mathematics, Statistic and Science 6(3) 321-324

10. Efina.G. (2011). Opportunities for insurance inclusion in Nigeria. Retrieved fromwww.cenfri.orgon June 27, 2018

11. Egbulaonu (2007) International Property-Liability Insurance Consumption, Journal of Risk and Insurance, 67(1), 391-410.

12. Ejumudo K. B. O. (2013) The Problematic of development planning in Nigeria: A critical discourse, developing Country Studies 3(4)

13. Enoka, R. (2012). History of motor insurance. Retrieved fromon August 9,2018 at www.insurance-fo secure.blogspot.com.

14. Ezema,C.A and Eche .A.U (2018) Measuring the shocks and dynamics of micro economic Variables to Insurance Performance in Nigeria,. Journal of banking,Financial Service and Insurance Research 8(2)

15. Greene, W. \& Segal, D. (2000). Profitability, growth and efficiency in the US Life insurance industry. Paper presented at workshop at the Hebrew University of

16. Jerusalem. Retrieved from www.citeseerx.ist.psu.edu on September 20, 2017.

17. Hassai \&Sümeg K (2008). "The relationship between Insurance and Economic Growth in Europe.A Theoretical and empirical analysis".Empirica, 35(4)

18. Ibrahim, A. M. (2013) Factors Influencing Performance of the Insurance Industry in Tanzania: The Case of Zanzibar Insurance CorporationMasters thesis, TheOpen University of Tanzania. Retrieved from www.repository.out.ac.tz on August 19, 2018 Investopedia

19. Kugler, M \&Ofoghi R (2005). Does insurance promote economic growth? evidence from the UK. Division of Economics, University of Southampton, UK

20. Libuli, D. O., Sakataka, W. and Wandera, R. (2014). An Assessment of Operational Strategies Influencing the Growth of Insurance Industryin Uasin Gishu County, Kenya International Journal of Managerial Studies and Research, 2 (10) PP 36-45

21. Mojekwu, J.N., Agwuegbo, S.O., Olowokudejo, F.F. (2011). "The Impact of Insurance Contributions on Economic Growth in Nigeria", Journal of Economics, 3(7), 444-451. 
22. Mururi, J. W. and Bosire, N. (2015).Determinants of capital structure decisions of listed insurance companies in kenya: A survey of insurance companies in Nakuru Town. International journal of scientific engineering and research 3(5), 78-85.

23. Marijuana C, (2009). "Insurance Sector development and Economic growth in Transition countries". Int. Res. J. Financ. Econom., issue 34.

24. National Bureau of Statistic (Nigeria).Nigeria Annual Abstract of Statistics (2009). Abuja, Nigeria: National Bureau of Statistics (Nigeria).

25. National Insurance Commission (2010). Annual Report and Audited Account.

26. Njuguna, G. W. \& Kimani, M. (2016). Assessment of financial factors affecting insurance penetration in Nakuru town, Kenya, International Journal ofEconomics, Commerce and Management, 4(9), 548-568

27. Nwankwo, G 0. (1991). Bank Management Principles and Practice Lagos, Malthouse Press Ltd

28. Nwoji, E. (2017). Insurance Sector Growth Rate Dwindles in Third Quarter 2017. Retrieved from www.thisdaylive.com on May 1, 2018.

29. Onyeka, K. R. (2006): Enhancing the Value of Insurance in Nigeria Through Paradigm Shifts. Journal of Chartered Insurance Institute of Nigeria Vol. 12 No. 3 July, pp. 16-19.

30. Okoko, E. (2006). Quantitative techniques in urban analysis, Ibadan, Kraft Books Limited.

31. Oye, A. J.(2014) National Development Strategies: Challenges and Options,nternational Journal of Humanities and Social Science Invention, 3(4)

32. Outreville, J. (1990). The Economic Significance of Insurance Market in Developing ountries. The Journal of Risk and insurance, 57,487-498.

33. Pen-Fen, Chin-Chiang, Chin-Feg (2011). How Does the Development of the Life Insurance Market Affect Economic Growth? Some International Evidence. Journal. International Development.

34. Vanishree, (2017). Insurance Penetration and Insurance Density. Retrieved from www.mrkt.co.in on May 1, 2018

35. Wadlamannati KC (2008). "Do Insurance Sector Growth and Reforms affect Economic Development? Empirical evidence from India". J. Appl. Econom. Res., 2(1): 43-86.

36. Ward, D \&Zurbruegg, R (2000). Does Insurance Promote Economic Growth? Evidence from OECD Countries. Journal of Risk Insurance, 67(4)489-506

37. Webb, I., Grace, M. F. \& Skipper, H.D (2002).The Effect of Banking and Insurance on the Growth of Capital and Output. Center for Risk Management and Insurance, Working Paper 02

38. Zou, H. \& Adams, M.B (1998). The corporate purchase of property insurance: Chinese evidence. Journal of Financial Intermediation, 56(15)1174-1180 World bank 2002 